\title{
HLA Types and Immune Reaction
}

\author{
Shunro Sonoda ${ }^{1}$, Toshinobu Fujiyoshi ${ }^{1}$, Shinji Yashiki $^{1}$, Masahiro Kuwayama ${ }^{1}$, \\ Hong Chuan Li ${ }^{1}$, Hong Lou ${ }^{1}$ And Carolina Lema Herrera ${ }^{1}$
}

\section{RESUMEN}

Los antígenos leucocitarios (HLA) están vinculados por genes altamente polimórficos, con el complejo mayor de histocompatibilidad localizando en el brazo corto del cromosoma 6. Dos contingentes distintos del gen del HLA se heredan de los padres en forma mendeliana y que se expresan codominantemente para producir dos sets de antígenos de HLA: A, B-C, DR y DQ, así como los fenotipos complementarios. El tipo de HLA y los haplotipos son útiles para la identificación individual y/o grupos genéticos en los seres humanos. Otra importante función de la diversidad del HLA es el reconocimiento inmunológico de los antígenos propios o ajenos. Los autoantígenos originados en células autólogas y los antígenos de origen exógenos son procesados en proteosomas para degradarlos a fragmentos peptídicos los que encajan especialmente de acuerdo a la particular configuración de las moléculas de HLA.

Los complejos HLA peptídicos son reconocidos por un repertorio de linfocitos $\mathrm{T}$ o $\mathrm{B}$ que expresan una respuesta inmune específica.

Las células $\mathrm{T}$ y $\mathrm{B}$ que reconocen antígenos autólogos son naturalmente destruidas, mientras que aquellas células expuestas a los antígenos exógenos sobreviven largamente y producen una respuesta amnéstica contra los mismos antígenos. Algunas células $\mathrm{T}$ pueden sobrevivir más de 30 años. Así, la memoria inmune a las células $\mathrm{T}$ o $\mathrm{B}$ es útil para la búsqueda de antiguas epidemias de enfermedades infecciosas sobrepasada por los distintos grupos étnicos. En ese sentido el estudio de HLA entre los andinos, así como los antecedentes que se refieren a su susceptibilidad por las infecciones por HTLV 1 son semejantes a las que expresan los japoneses del sur.

1 Department of Virology, Faculty of Medicine, Kagoshima University, Japan.

\section{INTRODUCTION}

Primitive life emerged 3 billion years ago on earth with continuous evolution of new species of genes since then. Cells and viruses co-evolved and established host-parasite relationships. The cells can be viewed as autonomous machines which reproduce macromolecules of nucleic acids, proteins and membrane structures incorporating small amino acid and lipid molecules as well as nucleotide precursors which are considered to have been ubiquitously available in the ancient sea waters. Biological interactions between primordial cells and parasites resulted in birth and death of new lives to make the variety of living organisms on the earth.

Horno sapiens evolved around 120,000 years ago developing more than 50,000 genes which are compiled into two strands of DNA, 3.7 meters of length. The DNA strands link the nucleotide sequences of exons and introns of genes to make up the individual haplotype of human chromosomes in the nucleus and mitochondria. The individual haplotype includes many diversified sequences of DNA which identify family or ethnic group and lineages. High polymorphism of human genes is evident in leukocyte antigen (HLA) genes which are composed of more than 500 distinct alleles (genes). Individual HLA haplotypes from maternal and paternal lineages constitute two sets of HLA-A, C, $\mathrm{B}, \mathrm{DR}$ and DQ alleles which are co-dominantly expressed in the children's cells. Thus, HLA alleles and haplotypes are useful genetic markers to investigate familial and ethnic backgrounds of human populations. HLA molecules encoded by HLA-A, B, C, DR and DQ alleles provide specific protein configurations which recognize the relevant binding motifs of self or non-self peptides to induce the immune response. Thus, HLA alleles define the individual repertoire of the immune system by specific combinations of HLA/peptide complexes which are made of exogenous or endogenous antigen peptides (epitopes). Biological interactions in ethnic groups of human populations result in long-lived T-cells with a memory of immunological impacts of 
exogenous antigens of parasites and other disease vectors.

This paper introduces recent advances in molecular genetics of HLA and peptide binding motifs with an ethnoepidemiological comparison of Andeans and Japanese in their immunogenetic background with regard to human T-cell leukemia viruses.

\section{Genetic polymorphism of the HLA system and the immune response}

The ancient environment of the earth was free of living organisms when inorganic and organic substances were first interacting to make chemical complexes. A primordal nucleic acid is thought to have been generated 3 billion years ago and evolved into a primitive RNA, then a catalytic RNA, and a polypeptide of enzymatic activity with reverse transcriptase to make DNA which replicated and enlongated to provide more sophisticated nucleic acids and proteins for making up cell components and concomitantly, RNA and DNA viruses (1). Thus, all species of cellular organisms including prokaryotes, eukaryotes, plants and animals are inherently subjected to viral infections which cause diseases due to cytopathic effects and tissue damage.

Both cellular and viral nucleic acids are changeable by mutations of nucleotide sequences during replication. Neutral mutations (synonymous nucleotide substituions) and functional mutations (non-synonymous nucleotide substitutions to code different amino acids ) accumulating in nucleic acid sequences produce genetic diversity to evolve new species of cellular and viral genes.

Human beings have diversified into thousands of

Dendogram of HLA-A genes

modified from Takahata et al. 1995A

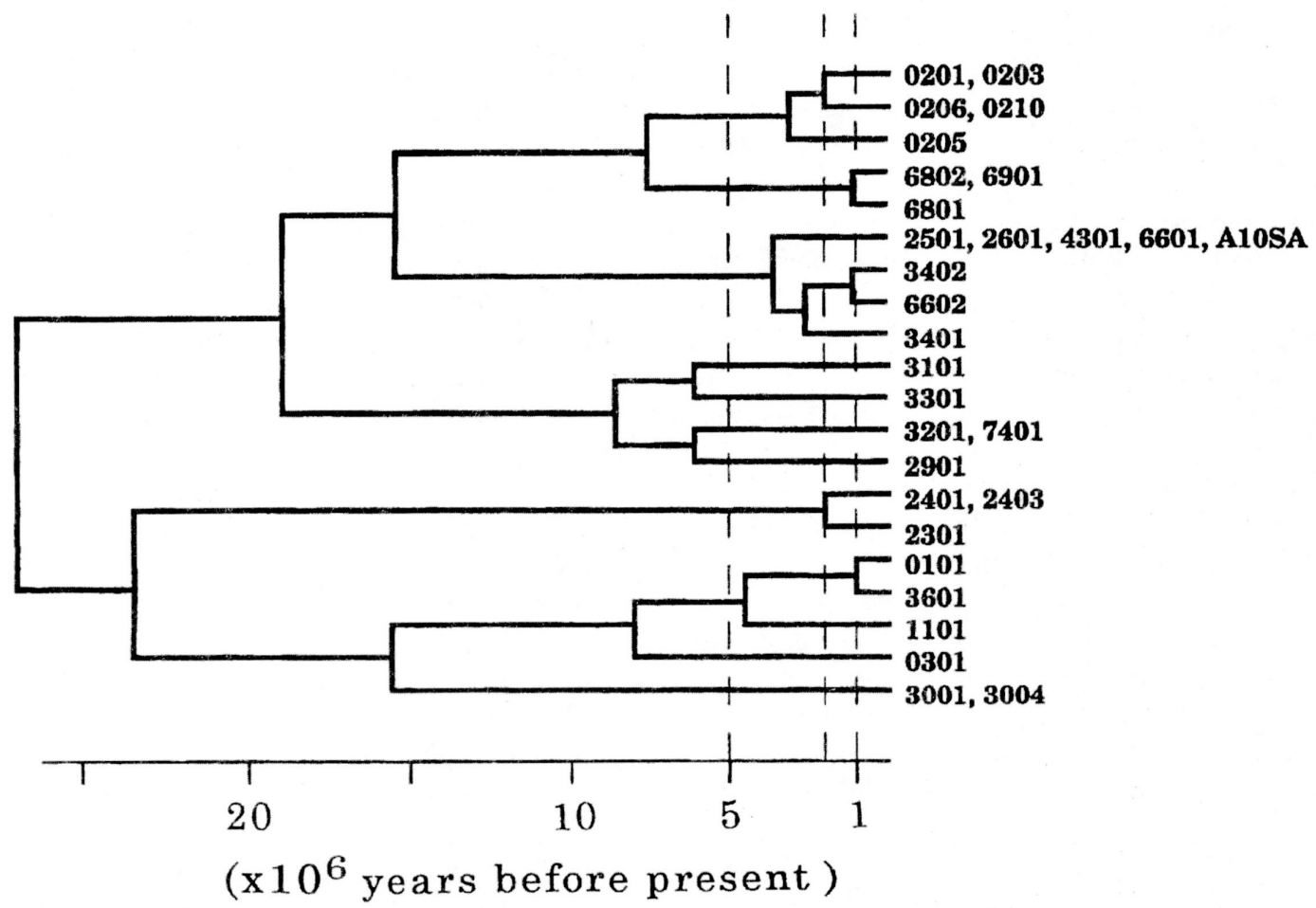

Fig. 1. Dendrogram of HLA-A. Genes HLA-A genes (alleles) have diversified into 30 alleles from two major branches of a genetic tree linked to common ancestral genes from the histocompatiblity complexes of the chimpanzee, gorilla and other primates. 


\section{Cellular Interaction in Antigen \\ Processing and Presentation}

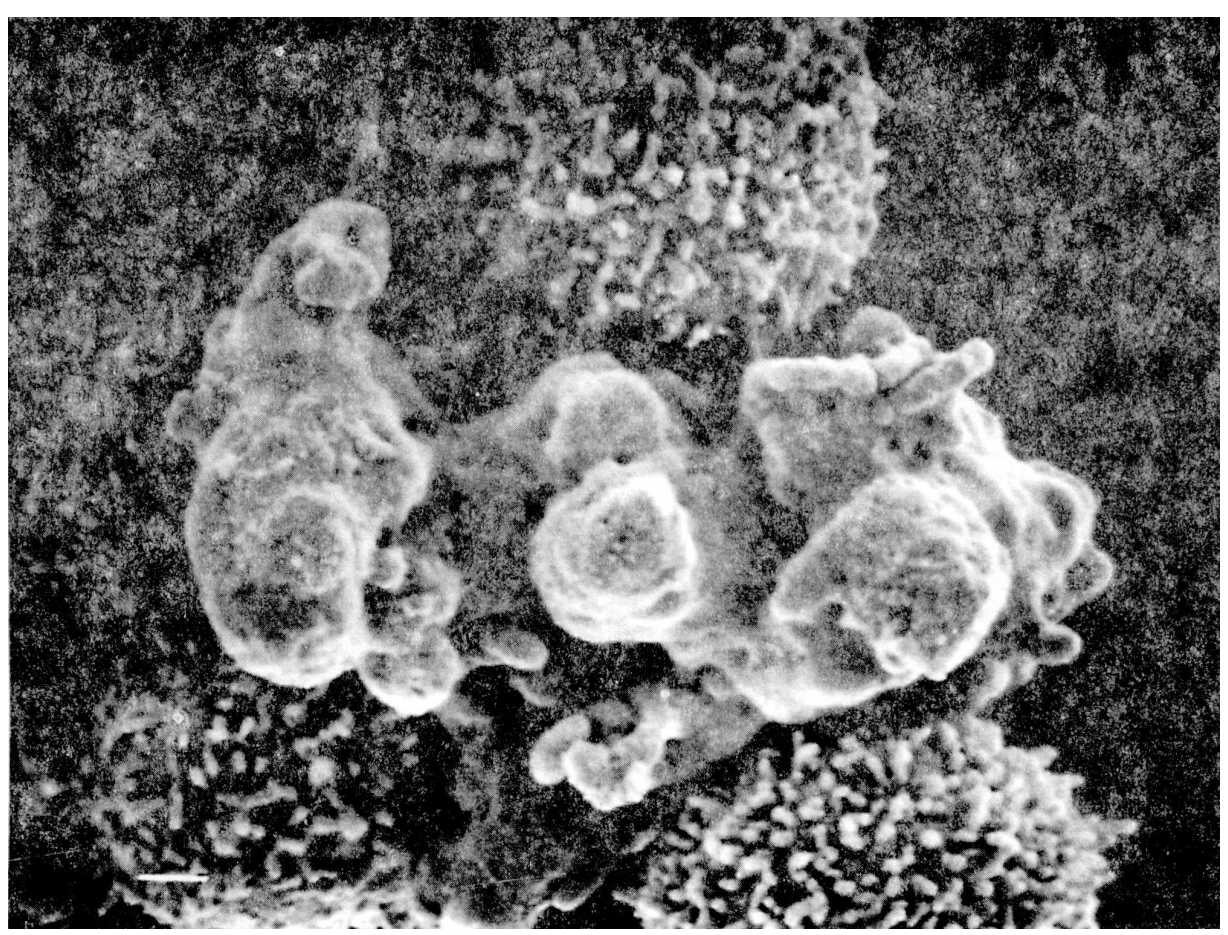

Fig. 2. Cellular Interactions in Antigen Processing and Presentation. Macrophage (ingesting bacteria) and Lymphocytes come in a close contact of their surfaces and cross talk in antigen processing and representation occur.

ethnic groups over the last 3 million years with polymorphic MHC (major histocompatibility complex) genes on chromosome 6 (Table 1), MHC genes do not evolve so rapidly that human leukocyte antigen (HLA) alleles have diverged from ancestral lineage of MHC genes of chimpanzee, gorilla and other primates in the evolution of modern human beings (Fig. 1). The polymorphic genes of HLA were impacted on infectious pathogens in an environment where specific peptide sequences were recognized by one of the HLA antigens composed of glycoproteins encoded from HLA-A, Cw, B, DR, DQ genes (2).

Eighteen families of viruses (6 DNA and 14 RNA viruses) are known to be pathogenic to man (3). Each virus looks for its host to infed and replicate its progeny. Some of the progeny viruses are mutated to evade immune attacks of the human host and to evolve new variants. Natural selection of humans and viruses results in evolution of new genes in tandem.

Immunological interactions between host and exogenous pathogens is complicated by the responses of phagocytic cells and lymphocytes, collaborating in antigen processing and presentation in vivo (Fig. 2). A specific structures of HLA molecules recognize peptide sequences of exogenous pathogens such as shown for the HLA*24 molecule and peptide anchor motifs of human T-cell leukemia virus type 1 (HTLV-I) (Fig. 3). Thus, individual HLA molecules determine the immune response to exogenous peptide antigens depending of such molecular fitness. Some individuals may be good or high immune responders and the others may be poor or low immune responders depending on the HLA/ peptide binding compatibility. 


\section{Natural history of infectious diseases}

Pandemies of infectious diseases are well documented in history. Viral infections resulting in small pox, rabies, polio, mumps, measles and flu are classical examples with repeated worldwide prevalence. Lassa virus, Ebola virus, Hantavirus, ATDS are newly emerging in the human world (Table 2). All the emerging and re-emerging viral diseases are a big challenge to human society so that their control is of major medical interest for health care programs in all countries. Vaccines for small pox, polio and measles can be successfull in preventing infections but vaccines for newly emerging viruses like Lassa,
Ebola and AIDS remain to be developed. This is a high priority.

\section{Human T-cell leukemia virus infections and diseases}

Human T-cell leukemia virus type I (HTLV-I) is causatively associated with adult T-cell leukemia (ATL) and HTLV-I-associated myelopathy/tropical spastic paraparesis (HAM/TSP) as well as other autoimmune diseases depend upon individual disease susceptibility (Fig. 4). ATL patients and their relatives are known to be low immune responders

\section{HTLV - I Peptide Anchor Motif (HLA - A24)}

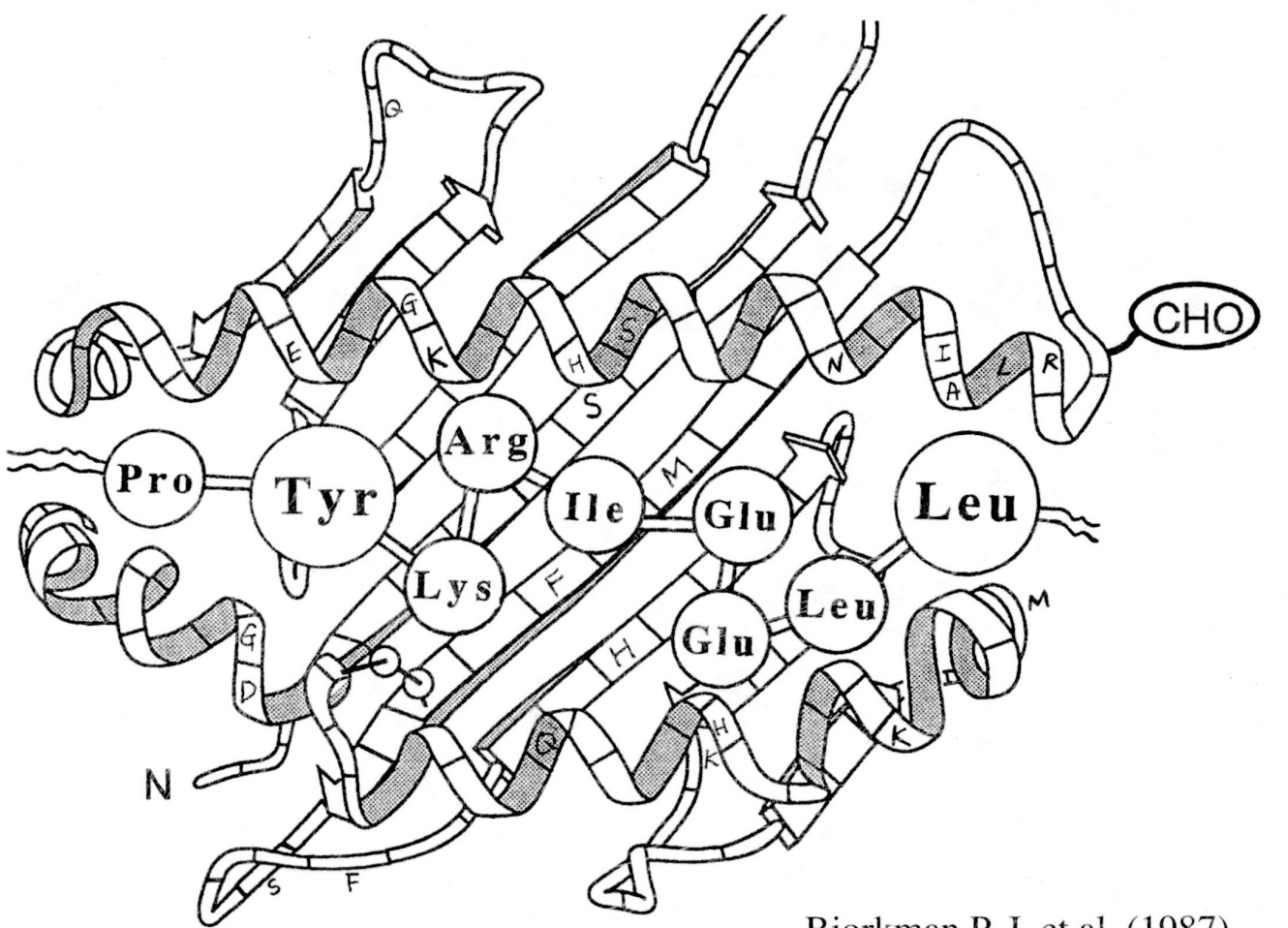

Bjorkman P. J. et al. (1987)

Yashiki S. et al. (1998 in prep.)

Fig. 3. HTLV-I Peptide Anchor Motif. The HLA-A24 molecule has two basic structures with a helix and b-sheet configurations to recognize a HTLV-I peptide sequence of 9 acids. The principal anchor motifs are Tyrosine at position 2 and Leucine at position 9, respectively binding arginine and methionine of the a-helix polypeptide structure of the HLA-A24 molecule. 


\begin{tabular}{|c|c|c|}
\hline \multicolumn{3}{|c|}{ Emerging Viruses } \\
\hline BC 2500 - & Polio & Egypt (Relief in Pyramid) \\
\hline BC $0400-$ & Mumpus & Greek (Hippokrates) \\
\hline AD 0200 - & Variola & India-China (Vaccination) \\
\hline ---- &.---- & --.-- \\
\hline 1969 & Lassa virus & Lassa fever \\
\hline 1969 & Enterovirus 70 & AHC (Apolo D) \\
\hline 1973 & Rotavirus & \\
\hline 1976 & Ebola virus & Ebola HF \\
\hline 1977 & Hantavirus & HFRS \\
\hline 1980 & HTLV-I & Adult T-cell leukemia \\
\hline 1982 & HTLV-II & \\
\hline 1983 & HIV-1 & AIDS \\
\hline 1986 & HIV-2 & \\
\hline 1988 & HHV6 & Examthem subitum \\
\hline 1989 & $\mathrm{HCV}$ & Hepatitis C \\
\hline 1991 & Guanarito virus & Venezuelan HF \\
\hline 1994 & Sabia virus & Brazilian HF \\
\hline \multicolumn{3}{|c|}{ Re-emerging Viruses } \\
\hline \multirow{4}{*}{\multicolumn{2}{|c|}{$\begin{array}{l}\text { Rabie virus } \\
\text { Dengue virus } \\
\text { Yellow fever virus } \\
\text { Hantavirus USA - NM }\end{array}$}} & Asia, S. America \\
\hline & & Asia, S. America \\
\hline & & Africa, S. America \\
\hline & & \\
\hline \multicolumn{3}{|c|}{ (HF with pulmonary syndrome) } \\
\hline
\end{tabular}

to HTLV-I pX peptides while HAM/TSP patients and their relatives are high HTLV-I pX responders. The low and high responsiveness are genetically determined by HLA-A and B alleles and the relevant peptide binding motifs. In fact, HLA-A*26 and B *40 of ATL patients lack any binding motifs to recognize HTLV-I Tax peptides. In contrast, HLA-A*24 and B*07 recognize numerous HTLV-I Tax peptides. HLA-A and B alleles typical of Japanese HAM/ TSP cases are also frequently found among Bolivian HAM/TSP patients although no detailed comparison has been made due to the relative lack of ATL patients in the Bolivian population (Table 3). However, a similar HLA background of ATL and HAM/TSP was found among Afro-Caribbean population in Jamaica. This ethnospecificity of HLA alleles and HTLV-I-associated diseases may be explained by a genetic tree of HLA-A lineage among these populations (Fig. 5). Japanese HLA-A*26 is linked in a common branch with HLA A68 and 34 associated with Jamaican ATL, and Japanese HLA-A*24 is close to HLA-A*23 and $A^{*} 30$ but far from the HLA-A*80 of Jamaican HAM/ISP. HLA studies thus provide an insight into immunogenetic back-

Table 2

\section{Phylogenetic tree of the HLA-A intron sequences}

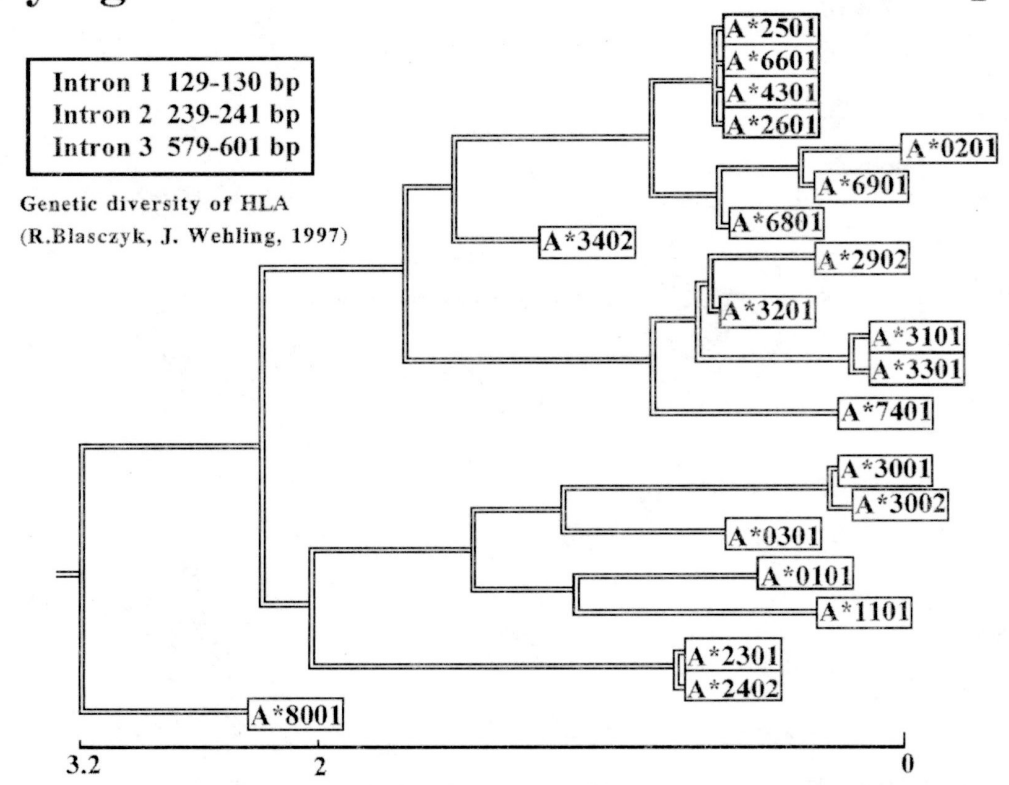

Fig. 4. HTLV-I Infection and Diseases. HTLV-I infected mothers transmit virus via breast milk to infants who become the second generation of HTLV-I carriers and develop diseases depending upon their genetic background. Adult T-cell leukemia (ATL) is segregated from other diseases such as infective dermatitis, HAM/ISP and other autoimmune diseases with HAAP, HAB and uveitis. 
Major HLA alleles of ATL and HAM/TSP

Ethnic groups ATL HAM/TSP

\begin{tabular}{|c|c|c|c|c|}
\hline Japanese & $\begin{array}{l}A * 26, A^{*} 31 \\
A^{*} 33, B^{*} 61 \\
B * 15, B * 44\end{array}$ & $\begin{array}{l}\text { DRBI*0901, *1301 } \\
\mathrm{DRBI}^{*} 1302, * 1401 \\
\mathrm{DRBI}^{*} 1406, * 1501\end{array}$ & $\begin{array}{l}A * 02, A^{*} 03 \\
A * 11, A * 24 \\
A * 24, B * 07 \\
B * 35, B * 51\end{array}$ & $\begin{array}{l}\text { DRB } 1 * 0101, * 0405 \\
\text { DRB1*0802, *803 } \\
\text { DRB1*1402, *1403 } \\
\text { DRB1*1502 }\end{array}$ \\
\hline Bolivian & No cases & & $\begin{array}{l}\mathrm{A} * 02, \mathrm{~A} * 24 \\
\mathrm{~A} * 28, \mathrm{~A} * 30 \\
\mathrm{~B} * 08, \mathrm{~B} * 35 \\
\mathrm{~B} * 51\end{array}$ & $\begin{array}{l}\text { DRB } 1 * 0301, * 701 \\
\text { DRB } 1 * 0802, * 1402\end{array}$ \\
\hline Jamaican & $\begin{array}{l}A * 01, A * 26 \\
A * 29, A * 30 \\
A * 33, A * 34 \\
A * 36, A * 74 \\
A * 80, B * 40 \\
B * 15, B * 44 \\
B * 53, B * 58\end{array}$ & $\begin{array}{l}\text { DRB } 1 * 1101, * 1301 \\
\text { DRB } 1 * 1401, * 1501\end{array}$ & $\begin{array}{l}A * 02, A * 03 \\
A * 11, A * 23 \\
A * 28, A * 68 \\
B * 07, B * 08 \\
B * 35, B * 49 \\
B * 57\end{array}$ & $\begin{array}{l}\mathrm{DRBl} * 0101, * 0301 \\
\mathrm{DRB1} * 0701, * 0802\end{array}$ \\
\hline
\end{tabular}

Table 3

\section{Phylogenetic tree of the HLA-A intron sequences}

\section{HTLV-I Infection and Diseases}

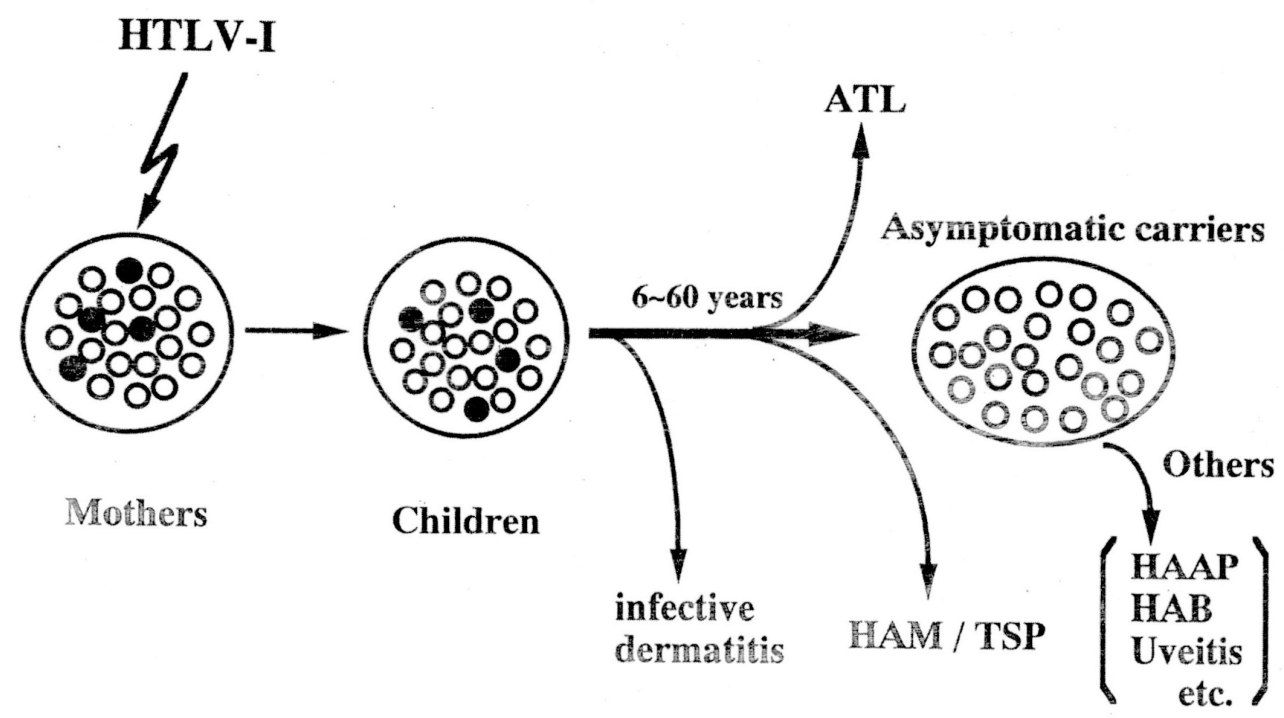

Fig.5. Phylogenetic tree of HLA-A intron sequences. HLA-A alleles are related in a tree of HLA-A intron sequences. HLA-A*26 is one of the major HLA alleles associated with Japanese ATL, while HLA-A*24 is associated with Japanese HAM/ISP. The HLA-A*26 and $A^{*} 24$ alleles are remote in their relationship and segregated in the phylogenetic tree. Jamaican ATL is linked with HLA-A *66, 68 while HAM/TSP is associated with HLA-A*023 and $A^{*} 03$ alleles. Bolivian HAM/TSP is found among carriers of HIA-A*24 and $A^{*} 11$ alleles. 


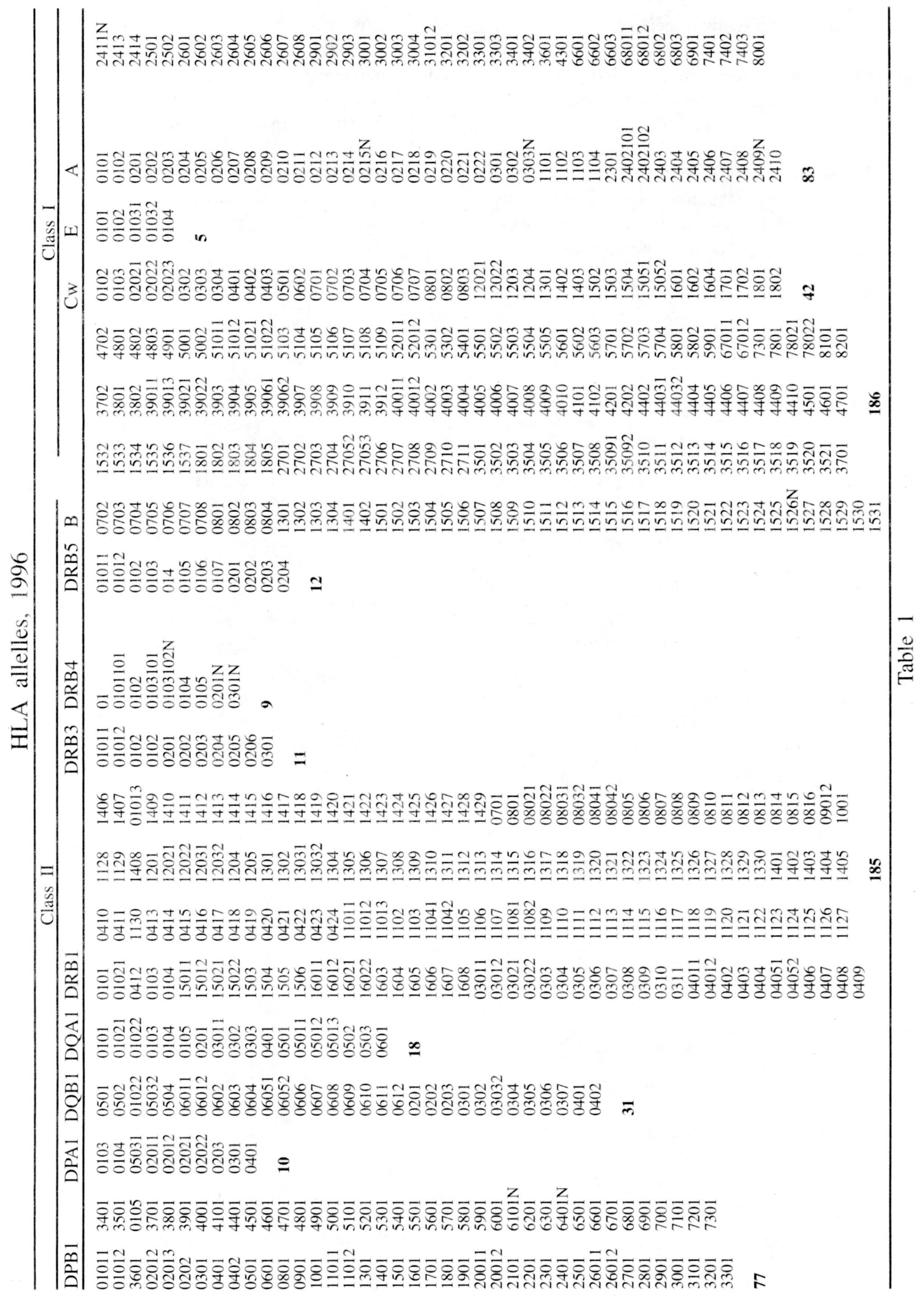


ground of diseases with respect to low and high immune responses against HTLV-I peptide antigens. It is conceivable that ATL and HAM/TSP offer the best model to investigate the HLA and immunogenetic background of diseases caused by one pathogenic species of virus, HTLV-I. This HTLV-I model might be useful to understand the immunogenetic background of other infections like hepatitis virus, papovavirus and herpes virus, naturally occurring among contemporany human populations.

\section{Aknowledgements}

The authors thank Drs. Luis Hurtado, Luisa Valentina, Mirth Camacho and Ronald Andrade for their support in the Bolivian HTLV study, Drs. Angela Manns and Barrie Hanchard for their collaboration in the Jamaican HTLV study and Miss Ranko Kawata for her secretarial assistance in our work.

\section{REFERENCES}

BECKER, Y. Molecular evolution of viruses-past and 1996 present. Kluwer Academic Publishers. Norwell, MA, USA.

BJORKMAN, P., SAPER, M., SAMRAOURI, B., BENNET, 1987 W. STROMINGER, J., WILLEY, D. The foreign antigen binding site and T-cell recognition regions of class I histocompatibility antigens. Nature 329:512-5 18

BLASCZYK, R., WEHLING, J. Sequence analysis of the HLA 1997 class I introns uncovers systematic diversity. In Genetic Diversity of IILA, Functional and Medical Implications (eds. D. Charon) EDK Medical and Scientific International Publisher. Sevres, France, pp. 146-148.

BROWNING, M., McMICKAEL, A. HLA and MHC, genes 1996 molecules and function. B105 Scientific Publishers Ltd. Oxford, UK.

TAKAHATA, N., SATTA, Y., KLEIN, J. Divergence time and 1995 population size in the lineage leading to modern human. Theor. Popul. Biol. 48:198-221.

WHITE, D., FENNER, F. Medical Virology. 4th Edition. 1994 Academic Press, Santiago CA. USA. 